\title{
IMPLEMENTASI NILAI SOSIAL UKHUWAH ISLAMIAH DI PONDOK PESANTREN
}

\author{
Oleh: \\ Iqbal Arpannudin \\ Jurusan PKnH Fakultas Ilmu Sosial Universitas Negeri Yogyakarta \\ arpannudin@uny.ac.id
}

\begin{abstract}
Abstrak
Pondok pesantren sebagai lembaga pendidikan dapat dijadikan sebagai sebuah model pengembangan konsep-konsep civics dalam rangka memenuhi life skill warga negara. Sebagian besar aktifitas di pondok pesantren adalah membangun kehidupan santri insan kamil yang mempunyai ketangguhan iman dan kemampuan beramal soleh yang membentuk nilai-nilai perilaku (behavioural values). Pengembangan nilai-nilai perilaku dalam pembentukan individu insan kamil sejalan dengan pengembangan struktur nilai dasar spiritual sebagai pengakuan terhadap martabat manusia (human dignity) yang memunculkan nilai tanggung jawab sosial sebagai bagian dari nilai sosial. Di dalam komunitas pesantren tanggung jawab sosial didasari oleh nilai spiritual yang terkandung dalam konsep ukhuwah islamiah.
\end{abstract}

Kata kunci: pesantren, nilai sosial, ukhuwah islamiyah.

\section{PENDAHULUAN}

Umat beragama dan lembaga keagamaan di Indonesia merupakan potensi besar dan modal dasar dalam pembangunan mental spiritual bangsa serta merupakan potensi nasional untuk pembangunan fisik materil bangsa Indonesia. Namun demikian salah satu masalah yang dihadap umat Islam di Indonesia sekarang ini adalah rendahnya rasa kesatuan dan persatuan sehingga kekuatan mereka menjadi lemah. Kelemahan umat Islam Indoensia ini terjadi hampir di semua sektor kehidupan, baik ekonomi, politik, sosial, maupun budaya.
Kelemahan ini tidaklah disebabkan karena sedikitnya jumlah umat Islam, melainkan rendahnya kualitas sumber daya manusianya. Salah satu penyebab rendahnya rasa persatuan dan kesatuan di kalangan umat Islam adalah karena rendahnya penghayatan terhadap nilai-nilai Islam, rendahnya solidaritas antar sesama muslim, saling mencurigai satu sama lain, dan faktor luar yang tidak kalah kuat merongrong keukhuwahan umat Islam ini. Oleh karena itu maka perlu dipikirkan kembali solusi untuk menyelesaikan permasalahan tersebut.

Melihat paparan di atas seyogyanya pendidikan agama tidak dapat diabaikan dalam penyelenggaraan pendidikan 
nasional. Dengan pendidikan dan pengajaran agama, warga negara akan memperoleh pendidikan moral dan budi pekerti yang akan membentuk bangsa Indonesia menjadi warga negara yang bermoral, bertanggung jawab, dan tahu nilai-nilai budaya yang dijunjung tinggi oleh bangsa Indonesia (Usman, 2011: 19).

Pendidikan dalam Islam memiliki makna sentral yang berarti pencerdasan secara utuh untuk mencapai kebahagiaan dunia akhirat (Mas'ud, 2003: 21). Pesantren adalah lembaga pendidikan tradisional Islam untuk memahami, menghayati, dan mengamalkan ajaran agama Islam (tafaqquh fiddin) dengan menekankan pentingnya moral agama Islam sebagai pedoman hidup bermasyarakat sehari-hari (Mastuhu, 1994: 6). Pesantren sama halnya dengan sekolah umum sebagai lembaga pendidikan yang mempersiapkan peserta didik. Pesantren sebagai lembaga pendididikan merupakan sarana utama setelah keluarga dalam pembentukan karakter santri / peserta didik. Hal ini senada dengan pendapat Crosnoe (2004: 267) tentang sekolah bahwa "Families and schools are two primary sources of social capital in the early life course", yang dapat diartikan bahwa keluarga seperti halnya sekolah adalah dua sumber utama modal sosial dalam pelajaran hidup awal.
Keberadaan pesantren di Indonesia dimulai sejak Islam masuk ke negeri ini dengan mengadopsi sistem pendidikan keagamaan yang sebenarnya telah lama berkembang sebelum kedatangan Islam. pesantren berkembang sebagai produk budaya Indonesia dalam pendidikan keagamaan dan sebagai lembaga pendidikan yang berandil besar terhadap proses penyelenggaraan pendidikan bangsa Indonesia. Dalam proses pendidikan pesantren berkembang sistem pendidikan keagamaan yang berbentuk pendidikan formal, non formal, dan informal yang senantiasa berkembang sesuai kebutuhan pendidikan masyarakat dengan mengikuti arus perkembangan jaman.

Pondok pesantren hadir menjawab kebutuhan untuk meningkatkan kualitas manusia Indonesia yang tidak hanya dalam pemajuan ilmu pengetahun dan dan teknologi, namun juga iman dan takwa. Itu semua diarahkan pada pencapaian kualitas hidup manusia agar memiliki kecakapan hidup yang seimbang antara duniawi dan akhirat. Pesantren juga berperan sebagai lembaga dan kaderisasi, untuk mencetak dan melahirkan santri pilihan yang akan meneruskan tugas dakwah para wali, da'i dan ulama, serta bertujuan menciptakan manusia yang berhidmat kepada masyarakat untuk menegakkan ajaran 
Islam di tengah-tengah masyarakat (Mastuhu, 1994: 87).

Sebagai lembaga pendidikan yang telah lama berkembang di negeri ini, pondok pesantren diakui memiliki andil yang sangat besar terhadap perjalanan sejarah bangsa, terutama dalam penyelenggaraan pendidikan keagamaan dengan berbagai bentuk pendidikan seperti, pendidikan formal, non formal, dan informal. Pondok pesantren sebagai sebuah komunitas pendidikan secara konsepsional relatif dapat dijadikan sebuah model pengembangan konsep-konsep civics dalam rangka memenuhi life skill warga negara.

Jika disandingkan dengan lembaga pendidikan Islam di Indonesia, pondok pesantren mempunyai ciri-ciri tersendiri, dan tradisi keilmuan yang berbeda dengan tradisi keilmuan lembaga-lembaga lain. Dengan demikian pesantren menjadi lembaga pendidikan yang unik, tidak saja karena keberadaannya yang sudah lama, tetapi juga karena kultur, metode dan penyajian yang diterapkan oleh lembaga pendidikan agama ini yang khas. Dari segi historis, menurut Nurcholis Madjid (Masyhud, 2003: 1) pondok pesantren tidak hanya identik dengan makna keislaman, tetapi juga mengandung makna keaslian Indonesia (indigenous).
Interaksi pembelajaran di lingkungan pondok pesantren melibatkan konsepkonsep Agama Islam terutama dalam pembentukan individu insan kamil yang mempunyai ketangguhan iman dan kemampuan beramal soleh ini menjadi hal yang perlu diseimbangkan dengan pembentukan life skill warga negara yang baik terutama warga negara yang mengetahui hak dan kewajiban bermasyarakat dengan ukhuwah islamiah sebagai acuan dasar bermasyarakat dalam Islam.

Kualitas hidup manusia Indonesia diharapkan dapat dipenuhi melalui proses pendidikan yang diarahkan untuk mencapai kecakapan hidup warga negara (life skill) yang diantaranya seperti yang digambarkan oleh World Health Organization bahwa kecakapan hidup sebagai keterampilan atau kemampuan untuk dapat beradaptasi dan berperilaku positif, yang memungkinkan seseorang mampu menghadapi berbagai tuntutan dan tantangan kehidupan secara efektif (Nurmalina, 2008: 65).

Pesantren memiliki kemampuan untuk meningkatkan kualitas hidup manusia Indonesia. Nilai nilai sosial di dalam pesantren dapat dijadikan pedoman, rujukan, dan penguatan karakter santri yang berakhlak mulia. Nilai merupakan perwujudan dari domain afektif pada diri 
seseorang sebagai kesatuan yang utuh yang menentukan perilaku dan kepribadian seseorang (Dzahiri, 1985). Oleh karena itu pesantren memegang peranan yang sangat penting untuk memberikan penguatan pilihan-pilihan nilai yang menentukan perilaku seseorang tersebut. Hal ini sebagaimana pendapat Sztompka bahwa nilai menjadi preference (pilihan) dari perilaku seseorang yang menjadi ukuran kepatutan atau kepantasan. Seseorang akan melakukan atau tidak melakukan sesuatu perbuatan tergantung pada sistem nilai yang dipegangnya (Rudi \& Haikal, 2014: 30).

Ketangguhan iman adalah nilai dasar spiritual yang harus dimiliki warga negara di lingkungan pesantren. Nilai dasar ini diarahkan untuk mampu menjangkau kesadaran supralogis yang membuat dirinya lebih dari sekedar "manusia" (man more than man) perwujudan dimensi spiritual ini adalah keimanan, sedangkan semangat keimanan itu disebut spiritualitas (Mulyana, 2004: 108). Tenaga spritual dapat menumbuhkan ketaatan berdasarkan kewajiban serta menjadi sebuah motivasi untuk membangkitkan, mempertahankan, dan mengontrol minat-minat beramal soleh. Muhammad Abduh (Dahlan, Yaswirman, Raya, \& Ritonga, 2000: 94) mendefinisikan amal soleh sebagai "segala perbuatan yang berguna bagi pribadi, keluarga, kelompok, dan manusia secara keseluruhan". Hal-hal yang berguna dalam pengertian amal soleh tersebut ditunjukan dalam bentuk nilai- nilai perilaku (behavioral values).

Amal soleh dalam pembelajaran Agama Islam menjadi hal yang perlu pengkajian bersama pembentukan nilainilai perilaku dalam kehidupan asyarakat Indonesia yang plural. Nilai-nilai yang dimaksud merupakan petunjuk-petunjuk yang terinternalisasi di dalam ekspresi perilaku yang ditampilkan seseorang (Mulyana, 2004: 26). Pengembangan nilainilai perilaku tersebut dirumuskan dalam tujuan utama pendidikan seperti yang dikemukakan oleh Mulyana (2004: 106) bahwa tujuan utama pendidikan adalah "menghasilkan kepribadian manusia yang matang secara intelektual, emosional, dan spiritual”. Karena itu, komponen esensial kepribadian manusia adalah nilai (values) dan kebajikan (virtues)". Konsep nilai (values) dan kebajikan (virtues) memiliki kecenderungan sama dengan konsep ketangguhan iman dan kemampuan beramal soleh terutama dalam pembentukan martabat manusia yang paripurna atau insan kamil.

Martabat manusia (human dignity) dianggap sebagai nilai yang tertinggi dalam membangun pendidikan yang efektif. Menurut UNESCO (Mulyana, 
2004: 107) mengungkapkan bahwa penghargaan terhadap martabat manusia dianggap sebagai nilai yang tidak terbatas dan dapat mendorong manusia untuk memilih nilai-nilai dasar yang berkisar di sekelilingnya. Nilai dasar ini, menurut UNESCO, meliputi nilai kesehatan, nilai kebenaran, nilai kasih sayang, nilai tanggung jawab sosial, nilai efisiensi ekonomi, nilai solidaritas global, dan nilai nasionalisme.

Penelitian ini hanya mengambil satu subsistem nilai dasar yaitu tanggung jawab sosial sebagai bagian dari nilai sosial dengan alasan bahwa dalam kehidupannya seorang peserta didik dapat melepaskan diri dari lingkungan sosial. Ia melakukan interaksi secara individual maupun kelompok. Interaksi yang dilakukan ditandai oleh adanya kepedulian terhadap orang lain, kebaikan antar sesama, kasih sayang, kebebasan, persamaan, dan penghargaan atas hak asasi sesamanya. Nilai sosial tersebut tergambar dalam rentang yang menurut Spranger adalah kadar nilai yang bergerak pada rentang antara kehidupan individualistik dengan yang altruistik (Mulyana, 2004: $34)$.

Pembentukan tanggung jawab sosial warga negara dalam lingkungan pembelajaran didasarkan pada pembentukan warga negara dalam merespon dan betindak di lingkungannya yang didasarkan kepada pendapat Gross dan Zeleny bahwa diperlukan tiga hal dalam hubungan antara warga negara dan lingkungannya antara lain kepekaan sosial (socially senstive), tanggung jawab sosial (socially responsible), dan kecerdasan sosial (socially intelegence) (Wahab \& Sapriya, 2011: 31).

Tanggung jawab sosial dalam komunitas pesantren berakar dari konsep ukhuwah islamiah yang mengikat komunitas tersebut. Dalam konteks komunitas pesantren, tanggung jawab sosial didasari oleh nilai spiritual yang terkandung dalam konsep ukhuwah islamiah. Konsep ukhuwah islamiah setidaknya terdapat empat hal, yaitu: (1) ukhuwah ubudiyah, (2) ukhuwah insaniah, (3) ukhuwah wathaniah, dan (4) ukhuwah fid dinul Islam (Shihab, 1996: 489).

Pendidikan dalam Islam memiliki makna yang sangat penting dan menyeluruh dan utuh untuk pembangunan manusia dalam mengarungi kehidupan dunia dan mempersiapkan kebahagiaan di akhirat kelak. Pesantren berperan sebagai lembaga dan kaderisasi, untuk mencetak dan melahirkan santri pilihan yang akan meneruskan tugas dakwah para wali, da'i dan ulama, serta bertujuan menciptakan manusia yang berhidmat kepada masyarakat untuk menegakkan ajaran 
Islam di tengah-tengah masyarakat (Mastuhu, 1994: 55-56).

Pesantren berawal dari pola pendidikan tradisional Islam telah menguatkan jati dirinya untuk mengikuti pola perkembangan kehidupan masyarakat. Pondok pesantren sebagai pendidikan Islam tradisional di Indonesia dan keberadaan sistem "boarding school ini dapat dilacak pada abad ke-18 (Srimulyani, 2007: 88) Namun hal tersebut, tidak lepas dari inti tugas utamanya yaitu mengamalkan ajaran agama Islam atau tafaqquhfiddin. Mastuhu (1994: 6) mengungkapkan bahwa pesantren adalah lembaga pendidikan tradisional Islam untuk memahami, menghayati, dan mengamalkan ajaran agama Islam dengan menekankan pentingnya moral agama Islam sebagai pedoman hidup bermasyarakat sehari-hari. Tujuan pendidikan di pesantren adalah menciptakan dan mengembangkan kepribadian muslim, yaitu yang bertakwa dan beriman, berakhlak mulia dan bermanfaat bagi masyarakat (Qomar, 2002: 6-7).

Proses pembelajaran di dalam pesantren dipengaruhi unsur-unsur yang membangun pondok pesantren tersebut. Unsur-unsur tersebut saling berkaitan dalam hal pengembangan pondok pesantren. Mastuhu (1994: 58) mengungkapkan tiga unsur utama dalam pesantren yaitu pelaku (kiai, ustadz, santri dan pengurus), sarana (masjid, pondok, kelas), dan prasarana (kurikulum, sumber belajar, cara belajar dan evaluasi belajar), seperti di bawah ini:

a. pelaku: Kiai, Ustadz, Santri, dan Pengurus;

b. sarana perangkat keras: mesjid, pondok, gedung sekolah;

c. Sarana perangkat lunak: tujuan, kurikulum, sumber belajar, cara belajar, dan evaluasi belajar.

Tipologi pesantren sendiri terdiri dari tiga bentuk yang ada, yaitu (1) salafi, Pesantren yang tetap mempertahankan pelajaran dengan kitab-kitab klasik dan tanpa diberikan pengetahuan umum, dan metodenya sebagaimana yang lazim diterapkan dalam pesantren salaf yaitu dengan metode sorogan, weton, dan bandongan (Masjkur, 2007: 26-27), (2) khalafi yang menerapkan sistem pengajaran klasikal (madrasi), memberikan ilmu umum dan ilmu agama serta juga memberikan pendidikan keterampilan (Hielmy, 1999: 35). Kedua bentuk ini setidaknya menghasilkan lulusan yang sesuai dengan harapan santri dan orang tuanya yaitu berakhlakhul karimah, tafaqquh fi al-din dan menguasai IPTEK (Mustari, 2010: 22) 
Bila dilihat dalam konteks kehidupan pesantren, di mana hubungan atau interaksi antar kiai, ustadz dan santri terjalin dengan erat. Hubungan yang terjalin erat itu bisa jadi, merupakan pengembangan dari tradisi dan nilai-nilai Islam yang ditanamkan oleh penyebar Islam dan disandarkan pada ajaran Rasullullah SAW. Seperti halnya cara memandang kehidupan secara keseluruhan sebagai ibadah, dan keikhlasan atau ketulusan belajar dan bekerja untuk tujuan bersama-sama. Nilainilai tersebut dijadikan landasan pijakan dan ruh dalam pengelolaan pesantren dengan tetap berpegang pada moral agama sebagai kunci sukses dalam hidup bersama, yang dalam hal ini adalah perilaku keagamaan yang memandang semua kegiatan sehari-hari sebagai ibadah kepada Allah Swt (Rudi \& Haikal, 2014). Mastuhu menyatakan pula bahwa kiai adalah tokoh kunci yang menentukan corak kehidupan pesantren (1994: 58). Namun, tidak menutup kemungkinan bahwa dua unsur lainnya berpengaruh besar terhadap perkembangan pesantren secara umum serta kualitas santri secara khusus.

Jika disandingkan dengan lembaga pendidikan Islam di Indonesia, pondok pesantren mempunyai ciri-ciri tersendiri, dan tradisi keilmuan yang berbeda dengan tradisi keilmuan lembaga-lembaga lain. Dengan demikian pesantren menjadi lembaga pendidikan yang unik, tidak saja karena keberadaannya yang sudah lama, tetapi juga karena kultur, metode dan peny ajian yang diterapkan oleh lembaga pendidikan agama ini yang khas yang mengandung mengandung makna kelokalan dalam konteks keindonesiaan. Karakteristik Islami ditampilkan oleh para pemangku kepentingan di pesantren (boarding school), sebagaimana yang diajarkan nabi Muhammad, yaitu Islam yang mengembangkan dan membangun intifah, tawassuth, musawah dan tawazun, serta menjadi agen peradaban nilai-nilai, norma dan pesan agama yang penuh harmoni, persatuan dan perdamaian, termasuk mempertahankan nilai-nilai dan ketertiban keharmonisan sosial di sekitarnya (Sirajuddin, 2010: 39).

\section{PEMBAHASAN}

Kurikulum berimbang dan terpadu yang dikembangkan pada pesantren khalafi pada dasarnya mengedepankan prinsip keseimbangan dalam pengembangan kurikulum antara kurikulum pesantren dan kurikulum umum atau yang dikembangkan oleh kementerian pendidikan. Tujuan prinsip keseimbangan dalam pengembangan kurikulum adalah untuk terjalinnya perpaduan yang lengkap dan menyeluruh yang satu sama lainnya saling memberikan sumbangan terhadap 
pengembangan pribadi peserta didik (Sagala, 2003).

Mata pelajaran yang dikembangkan dibagi menjadi mata pelajaran agama dan umum. Hal tersebut bertujuan untuk membentuk karakter yang handal dalam bidang keilmuwan dan kemampuan interaksi sosial anak yang berlandaskan agama dan akhlakul karimah. Jenis pesantren khalafi menerapkan sistem pengajaran klasikal (madrasi), memberikan ilmu umum dan ilmu agama serta juga memberikan pendidikan keterampilan (Hielmy, 1999: 35). Oleh karena itu, hal tersebut mengedepankan prinsip keseimbangan untuk pola pendidikan pesantren yang berlandaskan pada nilai dasar spiritualitas berupa ketangguhan iman. Perwujudan dimensi spiritual adalah keimanan akan menyertai minat beramal soleh yang berupa behavioral values yang merupakan petunjuk-petunjuk yang terinternalisasi dalam ekspresi prilaku yang ditempilkan seseorang (Mulyana, 2004). Behavioral values ini dikembangakn santri di pesantren setidaknya dalam tiga ranah yaitu kelas, masjid dan asrama. Ranah atau unsur ini saling berkaitan dalam hal pengembangan pondok pesantren. Lebih luas lagi Mastuhu (1994: 58) mengungkapkan tiga unsur utama dalam pesantren yaitu pelaku (kiai, ustadz, santri dan pengurus), sarana (masjid, pondok, kelas), dan prasarana (kurikulum, sumber belajar, cara belajar dan evaluasi belajar). Kiai adalah tokoh kunci yang menentukan corak kehidupan pesantren. Namun, tidak menutup kemungkinan bahwa dua unsur lainnya berpengaruh besar terhadap perkembangan pesantren secara umum serta kualitas santri secara khusus. (Mastuhu, 1994).

Proses interaksi sosial kewarganegaraan santri dalam lingkup poros kelas terikat oleh keharusan pencapaian kurikulum sekolah termasuk bidang mata pelajaran umum Pendidikan Kewarganegaraan. Bahan Pendidikan Kewarganegaraan menurut Nu'man Somantri (Nurmalina, 2008) harus mampu menumbuhkan berpikir kritis, analitis, dan kreatif agar siswa dapat melatih diri dalam berpikir, bersikap, dan berbuat sesuai dengan perilaku demokratis terbawa juga dalam proses interaksi di ranah pesantren baik di masjid, kelas, dan asrama serta dalam organisasi siswa di lingkungan pesantren tersebut

Pesantren tidak hanya berfungsi sebagai lembaga pendidikan tetapi juga lembaga sosial dan penyiaran agama (Mastuhu, 1994: 111). Sistem pendidikan pesantren didasari, digerakkan, dan diarahkan oleh nilai-niai kehidupan yang bersumber pada ajaran dasar Islam. Ajaran Islam ini menyatu dengan struktur 
kontekstual atau realitas sosial yang digumuli dalam hidup keseharian. Hal inilah yang mendasari konsep pembangunan dan peran kelembagaaan pesantren (Malik, 2005: 4).

Oleh karena itu harapan besar bahwa pesantren diharapkan mampu mencetak kader-kader agamawan (ulama) yang mampu memainkan peran kenabiannya pada masyarakat secara umum. Oleh karena itu tujuan kaderisasi ulama di pondok pesantren sesuai dengan tujuan pendidikan pesantren secara umum yang diungkapkan Mastuhu (1994: 55-56) yaitu menjadi pelayan masyarakat sebagaimana kepribadian Nabi Muhammad (mengikuti sunah Nabi), mampu berdiri sendiri, bebas, dan teguh dalam kepribadian, menyebarkan agama atau menegakkan Islam dan kejayaan umat Islam di tengahtengah masyarakat dan mencintai ilmu dalam rangka mengembangkan kepribadian Indonesia.

Konsep boarding school sebagai bentuk model pengembangan pondok pesantren dalam lembaga pendidikan yang maju dan bersaing untuk mengembangkan ilmu pengetahuan dan keterampilan yang berbasis pada nilai-nilai dasar spiritual. Jika disandingkan dengan lembaga pendidikan Islam di Indonesia, pondok pesantren mempunyai ciri-ciri tersendiri, dan tradisi keilmuan yang berbeda dengan tradisi keilmuan lembaga-lembaga lain. Dengan demikian pesantren menjadi lembaga pendidikan yang unik, tidak saja karena keberadaannya yang sudah lama, tetapi juga karena kultur, metode dan penyajian yang diterapkan oleh lembaga pendidikan agama ini yang khas yang mengandung mengandung makna kelokalan dalam konteks keindonesiaan. Karakteristik Islami ditampilkan oleh para pemangku kepentingan di pesantren (boarding school), sebagaimana yang diajarkan nabi Muhammad, yaitu Islam yang mengembangkan dan membangun intifah, tawassuth, musawah dan tawazun, serta menjadi agen peradaban nilai-nilai, norma dan pesan agama yang penuh harmoni, persatuan dan perdamaian, termasuk mempertahankan nilai-nilai dan ketertiban keharmonisan sosial di sekitarnya (Sirajuddin, 2010: 39). Oleh karena itu melalui model pengembangan ini maka bermunculan sumber daya manusia yang berkompetensi dalam ilmu pengetahuan dan akhlaqul karimah.

Pembelajaran model asrama (boarding school) semacam pesantren ini bisa jadi merupakan sebuah harapan ditengah situasi persekolahan sekarang ini yang kurang maksimal memberikan layanan penuh karena dibatasi oleh jam sekolah ditengah kesibukan keluarga yang akhirnya mempercayakan penuh sekolah 
untuk pendidikan anak-anaknya. Tak jarang terjadi hubungan antara guru dengan murid, antara anak dengan orang tua bersifat impersonal, bagaikan hubungan pembeli dengan pelayan toko (Nurrohman, 2003: 92). Dalam hubungan semacam itu hampir-hampir tidak ada keterikatan batin. Lain halnya kalau ada sekolah yang berbentuk atau memiliki asrama, atau keluarga yang orang tua sangat intens hubungannya dengan anak-anaknya, tentu hubungan guru dan murid atau orang tua dan anak menjadi lebih bersifat personal.

Pembelajaran sistem boarding school menyatukan antara pembelajaran reguler dengan pembelajaran nilai pengabdian terhadap agama, masyarakat, dan negara sebagai perwujudan ibadah kepada Allah. Kegiatan pembinaan santri oleh pembina menjadi bagian utama dalam pembelajaran nilai dengan proses utama pembentukan kader ulama Muhammadiyah dengan konsep islahiyah dan konsep tabsyiriah sebagai salah satu bentuk pembangunan karakter untuk membentuk jati diri para santri yang berakhlakul karimah dalam bermasyarakat, berbangsa, dan bernegara. Sebagaimana muhammadiyah sebagai basis ideologi yang mendasari banyak pesantren di Indonesia memandang Islam yang berkemajuan menyemaikan benihbenih kebenaran, kebaikan, kedamaian, keadilan, kemaslahatan, kemakmuran, dan keutamaan hidup secara dinamis bagi suluruh umat manusia (Nashir, 2015).

Proses perubahan dalam pembelajaran dikembangkan dalam pembelajaran nilai dalam bentuk nilai perilaku (behavioural values) yang ditampilkan dalam setiap individu-individu santri sebagai bagian dari lingkup masyarakat yang memiliki aturan baku berdasarkan ajaran Islam. Oleh karena itu pengalaman belajar mereka tidak hanya di dalam kelas namun terpadu dalam lingkup siklus kehidupan mereka sehari-hari di pondok. Hal ini sebagaimana tawaran Mead (Budimansyah \& Suryadi, 2008) tentang pendekatan pembiasaan. Menurutnya dalam pendekatan ini pengalaman anak yang sedang tumbuh menjadi fokus utama yang berarti sekolah harus mampu mensinergiskan antara kehidupan riil siswa dengan pengalaman belajat yang diperoleh di sekolah. Pondok pesantren harus mendukung upaya pengembangan pembelajaran nilai sosial kewarganegaraan dengan mengedepankan sarana-sarana pembelajara di lingkungan pondok pesantren sebagai miniatur masyarakat. Oleh karena itu menurut Nurrohman (2003: 92) dalam kondisi seperti terakhir inilah sosialisasi nilai kiranya baru akan efektif dan sungguh beralasan kalau banyak orang mengatakan bahwa sistem sekolah dewasa ini baru 
berhasil menanamkan nilai dalam ranah kognitif, belum masuk wilayah afeksi, psikomotor, ataupun living together (kesadaran hidup bersama).

Kegiatan ekstrakulikuler di lingkungan pondok pesantren khalafi tidak berneda dengan sekolah pada umumnya. Sama halnya dengan keberadaan sekolah sebagai lembaga pendidikan merupakan salah satu tempat mempersiapkan generasi muda mendatang menjadi manusia dewasa dan berbudaya (Dzahiri, 1985). Hal ini mengandung pengertian bahwa perhatian sekolah sebagai lembaga pendidikan tidak hanya menitikberatkan dalam aspek kognitif, tetapi aspek afektif dan psikomotoriknya.

Aspek kognitif berhubungan dengan perilaku berfikir, mengetahui dan pemecahan masalah. Aspek afektif berhubungan dengan sikap, nilai-nilai, apresiasi dan termasuk penyesuaian peranan sosial kewarganegaraan yang berbasis ukhuwah islamiah. Disamping itu, aspek psikomotor berhubungan dengan keterampilan yang bersifat manual dan motorik. Oleh karena itu pencapaian tujuan dalam rangka pengembangan pendidikan bagi santri tidak hanya di dalam kelas saja namun dalam proses yang lainnya seperti kegiatan ekstrakurikuler yang dipilih oleh para santri yang bentuknya beragam, baik itu ekstrakurikuler pengembangan diri, study club, olahraga dan bela diri.

Pengorganisasian santri untuk pembelajaran nilai sosial di poros kelas dan mesjid bisa dilakukan dengan metode ceramah (tak'lim), diskusi (mujadalah), dan pemecahan masalah-masalah sosial kewarganegaraan (problem solving) dengan banyak menggunakan model VCT (Value Clarification Technique). Selain itu dalam kegiatan pembinaan di poros asrama metode bisa menggunakan model uswatun hasanah dengan pembina sebagai role model yang ditiru santri dan motode pembiasaan dengan keberadaan tata tertib sebagai model kontrak sosial dari model yang lebih luas dalam kontrak sosial bermasyarakat dan bernegara. Pentingnya pola role model ini bahwa karakteristik Islam dikembangkan oleh stakeholder di pesantren sebagaimana yang diajarkan Nabi Muhammad, yaitu Islam yang mengembangkan dan membangun intifah, tawassuth, musawah dan tawazun, serta menjadi agen peradaban nilai-nilai, norma dan pesan agama yang penuh harmoni, persatuan dan perdamaian, termasuk mempertahankan nilai-nilai dan ketertiban keharmonisan sosial di sekitarnya (Sirajuddin, 2010: 39).

Ukhuwah Islamiah terbentuk karena komponen pembelajaran yaitu individu santri bersama komponen yang 
membelajarakan yaitu ustad/ustadzah merasa pernah ada dalam satu kesatuan proses belajar hal ini sebagaimana pandangan oleh Shihab (1996: 499) bahwa untuk memantapkan ukhuwah islamiah, yang dibutuhkan bukan sekedar penjelasan segi-segi persamaan pandangan agama, atau sekedar toleransi mengenai perbedaan pandangan, melainkan yang lebih penting lagi adalah langkah-langkah bersama yang dilaksanakan oleh umat, sehingga seluruh umat merasakan nikmatnya makna dari ukhuwah islamiah dalam pembelajaran nilai sosial yang dilakukan tidak hanya dalam unsur pembelajar namun dari unsur yang membelajarkan baik dari pimpinan pondok, pembina, atau ustad/ustadzah.

Ukhuwah Islamiah merupakan hubungan sesama muslim tanpa membedakan luas dan sempitnya kapasitas hubungan, mulai dari hubungan keluarga, masyarakat kecil sampai hubungan antar bangsa, hubungan ini mempunyai bobot religius (Hasan, 2003: 185). Dengan demikian pentingnya ukhuwah yang merupakan perekat persaudaraan sesama muslim yang harus senantiasa dipelihara melintasi batas-batas teritorial suku bangsa dan teritorial negara. Ukhuwah Islamiah merupakan menifestasi umat yang beriman dan bertakwa sebab ukhuwah Islamiyah tidak akan lepas dari keduanya. Ketundukan dan kelembutan hati yang termanifestasikan dalam bentuk kasih sayang kepada sesama manusia yang sangat tergantung pada interaksi umat Islam terhadap ajarannya.

\section{SIMPULAN}

Pendidikan dalam Islam memiliki makna yang sangat penting dan menyeluruh dan utuh untuk pembangunan manusia dalam mengarungi kehidupan dunia dan mempersiapkan kebahagiaan di akhirat kelak. Pondok pesantren sebagai lembaga pendidikan dijadikan sebagai sebuah model pengembangan konsepkonsep civics dalam rangka memenuhi life skill warga negara. Semua aspek kegiatan pembelajaran santri dikembangkan dalam seluruh lingkup kegiatan santri di lingkungan pondok. Lingkup kegiatan santri pada kenyataanya dapat dimisalkan seperti miniatur masyarakat luar pesantren. Proses perubahan dalam pembelajaran dikembangkan dalam pembelajaran nilai dalam bentuk nilai perilaku (behavioural values) yang ditampilkan dalam setiap individu-individu santri sebagai bagian dari lingkup masyarakat yang memiliki aturan baku berdasarkan ajaran Islam. Oleh karena itu pengalaman belajar mereka tidak hanya di dalam kelas namun terpadu dalam lingkup siklus kehidupan mereka sehari-hari di pondok. 
Pondok pesantren harus mendukung upaya pengembangan pembelajaran nilai sosial kewarganegaraan dengan mengedepankan sarana-sarana pembelajara di lingkungan pondok pesantren sebagai miniatur masyarakat. Pembelajaran di dalam pondok pesantren sangat penting dengan alasan bahwa sistem sekolah dewasa ini baru berhasil menanamkan nilai dalam ranah kognitif, belum masuk wilayah afeksi, psikomotor, ataupun living together (kesadaran hidup bersama).

Proses perubahan bagi para santri yang tersusun secara sistematis dalam sebuah visi misi pondok untuk mencapai setiap tujuan-tujuan pembelajaran dibentuk dalam miniatur masyarakat luar tersebut. Nilai sosial ukhuwah islamiah tertanam dalam diri santri yang ditempa dalam proses pembelajaran dan dari tiga ranah dalam lingkup pesantren selama mereka di pondok.

\section{DAFTAR PUSTAKA}

Budimansyah, D., \& Suryadi, K. (2008). PKN dan Masyarakat Multikultural. Bandung: Program Studi Pendidikan Kewarganegaraan Sekolah Pascasarjana Universitas Pendidikan Indonesia.

Dahlan, H. A. A., Yaswirman, Raya, A. T., \& Ritonga, D. B. G. (2000). Ensiklopedia Hukum Islam. Jakarta: PT. Ichtiar Baru Van Hoeve.
Dzahiri, A. K. (1985). Strategi Pengajaran Afektif Nilai, Moral, VCT, dan Games dalam VCT. Bandung: Jurusan Pendidikan Moral Pancasila Dan Kewarganegaraan FPIPS IKIP Bandung.

Hasan, T. (2003). Prospek Islam Dalam Menghadapi Tatanan Zaman. Jakarta: Lantabora Press.

Hielmy, I. (1999). Pesan Moral Dari Pesantren. Bandung`: Nuansa.

Malik, J. (2005). Pemberdayaan Pesantren. Yogyakarta: Pustaka Pesantren.

Mas'ud, A. (2003). Menuju Paradigma Islam Humanis. Yogyakarta: Gema Media.

Masjkur, A. (2007). Integrasi Sekolah ke Dalam Sistem Pendidikan Pesantren (1st ed.). Surabaya: Diantama.

Mastuhu. (1994). Dinamika Sistem Pendidikan Pesantren. Jakarta: INIS.

Masyhud, S. (2003). Manajemen Pondok Pesantren. Jakarta: Diva.

Mulyana, R. (2004). Mengartikulasikan Pendidikan Nilai. Bandung: Alfabeta.

Mustari, M. (2010). Pesantren Training in Tasikmalaya Regency. International Journal of Pesantren Studies, 4(1), 19-32.

Nashir, H. (2015). Memahami Ideologi Muhammadiyah. Yogyakarta: Suara Muhammadiyah.

Nurmalina, K. S. (2008). Memahami Pendidikan Kewarganegaraan. Bandung: Laboratorium PKn Universitas Pendidikan Idonesia.

Nurrohman. (2003). Sosialisasi Nilai Di Pesantren. Apa dan Bagaimana? Jurnal Kependidikan Islam, 1 Februari(1), 83-93.

Qomar, M. (2002). Pesantren: dari transformasi metodologi mеnuju 
demokratisasi institusi. Jakarta: Erlangga.

Rudi, L., \& Haikal, H. (2014). Modal Sosial Pondok Pesantren. Jurnal Harmoni Sosial, 1, 27-42.

Sagala, S. (2003). Konsep dan Makna Pembelajaran. Bandung: Alfabeta.

Shihab, M. Q. (1996). Wawasan Al-Quran. Bandung: Mizan.

Sirajuddin, M. (2010). The Application of Multicultural Education In Pesantren (A Case Study in the Pesantren Pancasila Bengkulu. International Journal of Pesantren Studies, 4(1), 34-52.

Srimulyani, E. (2007). Muslim Women and Education in Indonesia: The pondok pesantren experience. Asia Pacific Journal of Education, 27(1), 85-99.

http://doi.org/10.1080/021887906011 45564

Usman, M. I. (2011). Pesantren Sebagai Lembaga Pendidikan Islam. Jurnal Ilmiah Lembaga Pendidikan Islam Pare-Pare Kediri.

Wahab, A. A., \& Sapriya. (2011). Teori dan Landasan Pendidikan Kewarganegaraan. Bandung: Alfabeta. 
Humanika, Vol. 16, Nomor 1, September 2016 